\title{
EDUCATION FOR SUSTAINABLE DEVELOPMENT: A STAKEHOLDER ANALYSIS BETWEEN A CHINESE AND SINO-FOREIGN UNIVERSITY
}

\author{
AYOTUNDE DAWODU, FRANKLYN AWONFOR, HAOYUE DAI, SHENGYU LI, \\ CHENGYANG WU, XIAOYAN YANG \& ZIYI YAN \\ The University of Nottingham Ningbo China, China
}

\begin{abstract}
As the development of Sino-foreign universities in the current decade has grown significantly, the differences between Sino-foreign universities and standard universities in China has become a key topic of discussion. There is a lack of comparative studies on Sino-foreign universities and Chinese universities, and even more so on topics such as sustainable development. Currently, campuses within China have a huge impact on resource depletion, environmental pollution and social interactions and development. Also, universities are key players in knowledge creation and transformation, talent cultivation and technical innovation, and nationally it is recognized that the growth and development of campuses is critical to the overall sustainable development within China. Thus, this research aims to enhance the Education for Sustainable Development (ESD) in China through understanding the strengths and weaknesses of the ESD approach between a Sino-foreign universities and normative universities. This is executed through stakeholder analysis, which involves identifying, categorizing, and investigating the relationship within university stakeholders with regard to ESD. Further analysis is conducted with an interest and influence matrix chart that determines the priorities and influences of university stakeholders. Two universities (Chinese university - Ningbo University and Sino-foreign universities - University of Nottingham Ningbo China) will be used as case studies within China to draw out the synergies and differences of ESD.

Keywords: sustainability, education for sustainable development, stakeholders, stakeholder analysis.
\end{abstract}

\section{INTRODUCTION}

In recent years, sustainable development (SD) has become a focal topic, and the term Education for Sustainable Development (ESD) has attracted public attention. ESD aims to develop knowledge, skills, values, attitudes, and people's behaviours in caring for the environment through environmental education, and it is widely accepted as one of the most significant parts of achieving sustainable development [1]. Among a great range of fields involving ESD, this paper focus on the stakeholder analysis in the context of ESD in a typical Chinese university and Sino-foreign university. Universities are leaders in education, research, and innovation [2]. They have a crucial role in promoting students' perception of sustainable development to grow as a sustainable development leader and support the transformation of sustainable societies [3].

The Chinese government highly values sustainable development in universities, which started in the 1990s [4]. In 2008, 32 top Chinese universities, led by the MOE, announced the Declaration of Building Sustainable Campuses, aiming to promote sustainable development among campuses in China. However, SD in Chinese universities is still in the early stage, and there are still gaps and issues in effectively executing ESD in Chinese universities. One of the gaps is regional differences caused by the size of China [5]. Other issues could be the lack of research of Chinese institutions and gaps between updated research and teaching materials. Also, Tan et al. [6] summarised the progress of green campuses in China and found that energy and resource efficiency is the major focus. Additionally, Wang et al. [7] used the five-point Likert scale questionnaire to compare sustainable development 
in public and private universities from students' perception and found that students in private universities have a higher level of sustainability perception. However, the studies on ESD are still limited, especially those with the methodology of stakeholder analysis and from the perspective of Sino-foreign universities.

In this study, China HEIs is the core of the stakeholder analysis considering ESD and how this can be enhanced across various university setups. i.e., fully Chinese university and Sinoforeign university. The Sino-foreign University is a growing classification of higher education institutions in China, with different curriculum settings, management structures from regular Chinese universities. As it stands, there is a lack of comparative studies on Sinoforeign universities and Chinese universities, and even more so on topics such as sustainable development. Campuses within China have a huge impact on the environment, social interactions, and development.

Thus, this research aims to enhance the Education for Sustainable Development (ESD) in China through understanding the strengths and weaknesses of the ESD approach between Sino-foreign universities and normative universities. Further analysis was conducted with an interest and influence matrix chart determining university stakeholders' priorities and influences. This matrix allows for a better understanding of the university's sustainability strength, structure and approach, and sustainable development direction. Additionally, two universities (Chinese university - Tongji University and Sino-foreign universities University of Nottingham Ningbo China) was used as case studies within China to draw out the synergies and differences of stakeholders in ESD. Ultimately, these results can help people to improve ESD in the future.

Hence, this paper aims at understanding the different stakeholders involved in ESD decision making in Sino-foreign and Chinese universities. In addition, the influences of the key stakeholders in achieving ESD goals. To achieve the aims of this study, several objectives were defined to ensure the completeness and reliability of the research process.

1. Identification of the different stakeholders in ESD decision making between Sinoforeign universities and Chinese universities and understand their current sustainability state.

2. Determine the stakeholders' influences and interests in achieving ESD goals and categories them into groups accordingly.

\section{LITERATURE REVIEW}

\subsection{The argument for stakeholder analysis in ESD in Chinese universities}

Many gaps and issues exist in effectively executing ESD in Chinese universities. The regional difference is one of the gaps. An important reason for this is that most undergraduate schools are located in the middle and eastern parts of China, and education in these regions has a long history, which means it is easier to promote ESD in the middle and eastern parts than in other parts of China [5]. Another reason could be provincial-level economic development. Current studies on the provincial ESD performance indicated that ESD in most regions of China is at a medium level. However, it is unbalanced across regions, and the level is synonymous with economic development at the provincial level. Research shows that while the coastal regions are more developed in terms of economic and social development, ESD also performs better in coastal regions of China than in the inner land.

A study conducted by Geng and Zhao [8] found that six out of 11 coastal regions in China are graded higher than "fair", while only five out of 20 non-coastal regions meet the "fair" standard. Other issues could be the lack of research of Chinese institutions and the gaps 
between updated research and old teaching materials. Progress has been made in the research of ESD. For example, Yuan and Zuo [9] used a visual assessment of sustainability in universities to investigate students' awareness of sustainability and their perceptions and found that students generally attached importance to sustainability issues. Tan et al. [10] summarised the progress of green campuses in China and found that green campus is developing at a rapid pace and the Chinese government strongly encourage developing green campus by giving policy and financial support. Li et al. [11] developed a methodology to analyse students' carbon footprint with a case study of Tongji University and found relations on students' energy consumption patterns, behavioural tendencies, and energy conservation willingness. Wang et al. [7] used a five-point Likert scale questionnaire to find out students' perceptions of sustainable development and compared the result of public and private universities. Except for the finding that students in private universities are of a higher level of sustainability perception, the result also shows that while students are most interested in sustainability commitment and the role university plays in sustainable development, they are least concerned about sustainability curricula and research. Even the mentioned studies had been done, the studies on ESD are still too few, especially those with the methodology of stakeholder analysis and from the perspective of Sino-foreign universities.

To achieve the goals of ESD, stakeholders need to share responsibilities and explore solutions. The influence of stakeholders needs to be considered since their actions influence the success or failure of achieving goals [12]. This includes any group or anyone affected. In the process, their impact and interests will be accessed. Regarding the impact of stakeholders, Leal Filho and Brandli [12] cited the following three points: First, higher education produces better results. In achieving ESD sustainable development, universities and stakeholders should collaborate, which can better understand market conditions and improve the social responsibility and reputation of universities. Second, it can increase the possibility of fair decision-making as the value collision of different stakeholders may generate more ideas and create common goals. Finally, it allows ideas to be refined before they are adopted [13]. Different stakeholders have different experiences in dealing with a matter, and they have different influences in society. The superposition of experience may allow the solution of the matter to be verified by the groups representing different interests.

\section{METHODOLOGY}

\subsection{Stakeholder identification}

Generally, the university stakeholders were classified into internal and external stakeholders [7], [14], as shown in Table 1. The identification of stakeholders in sustainable development commenced from the basic framework, with the people in the table as the focus group. The process started with the search on the targeted university's official website, where detailed information of the stakeholders was obtained. Snowballing was proceeded in some cases via the interviews of the focus group to collect suggestions on the unclear boundary of the stakeholder group. After the identification of the different stakeholder groups, all the necessary members in the various groups were considered, and sub-groups were established for clarification.

\subsection{Stakeholder influence and interest ranking}

Stakeholder groups have different interests and influences on sustainable campus development, contributing to different levels. In this part, stakeholder groups were scored 
Table 1: Basic framework for stakeholder classification.

\begin{tabular}{|l|l|}
\hline Internal stakeholders & External stakeholders \\
\hline University management & Community \\
\hline Faculty & Alumni \\
\hline Staff & Funding agency \\
\hline Students & Government \\
\hline Internal stakeholders & \\
\hline
\end{tabular}

with 14 dimensions of sustainability (Table 2), summarised from the study for Chinese universities by Shuqin et al. [15] and literature review of several existed campus sustainability tools by Alghamdi et al. [16]. The different stakeholder groups were scored with " 1 " if they were proven to be interested in a particular dimension, representing that all dimensions, in this case, were equally weighted; else, this group was scored with " 0 " in this dimension. In the interest analysis, each group got a maximum of 14 points, and the points each group got meant the number of aspects they were interested in.

Table 2: Description of different stakeholders' categories.

\begin{tabular}{|l|l|}
\hline Stakeholder influence (sustainability dimensions) & Stakeholder interest \\
\hline Urban ecology and biodiversity & Organizational impact \\
\hline Reducing energy & Education and training impact \\
\hline $\begin{array}{l}\text { Governance dimension - institutional governance } \\
\text { maintenance and management }\end{array}$ & Knowledge and research impact \\
\hline Sustainable site planning and construction & Environmental impact social impact \\
\hline Water & Social impact \\
\hline Waste & Economic impact \\
\hline Transport & Organizational impact \\
\hline $\begin{array}{l}\text { Social operations and engagement (Engagement } \\
\text { on campus) }\end{array}$ & \\
\hline Financial operations & \\
\hline Education dimension & \\
\hline Research dimension & \\
\hline Sustenance, security, and safety (resilience) & \\
\hline Health and wellbeing & \\
\hline Smart campus & \\
\hline
\end{tabular}

As to the influence, stakeholders were assessed in six dimensions (Table 2), adapted from the study by Kioupi and Voulvoulis [17], which considered the fundamental aspects of sustainability and function of the university. The different stakeholder groups were scored with " 1 " if they were proven to have influence in a particular dimension, representing that all dimensions, in this case, were equally weighted; else, this group was scored with " 0 " in this dimension. In influence analysis, each group got a maximum of six points, and the points each group got meant the number of aspects they had influence. 


\subsection{Stakeholder categorization}

Based on the marked score, stakeholder groups were classified into four categories based on an existed interest-influence matrix [18] with corresponding characteristics shown in Fig. 1 (high influence, interested people; high influence, less interested people; low influence interested people; and low influence, less interested people (Table 3). In interest analysis, stakeholder groups scored 1 to 7 were placed in "low interest", scored 8 to 14 were placed in "high interest". As to the influence analysis, stakeholder groups scored 1 to 3 were placed in "low influence", scored 4 to 6 were placed in "high influence".

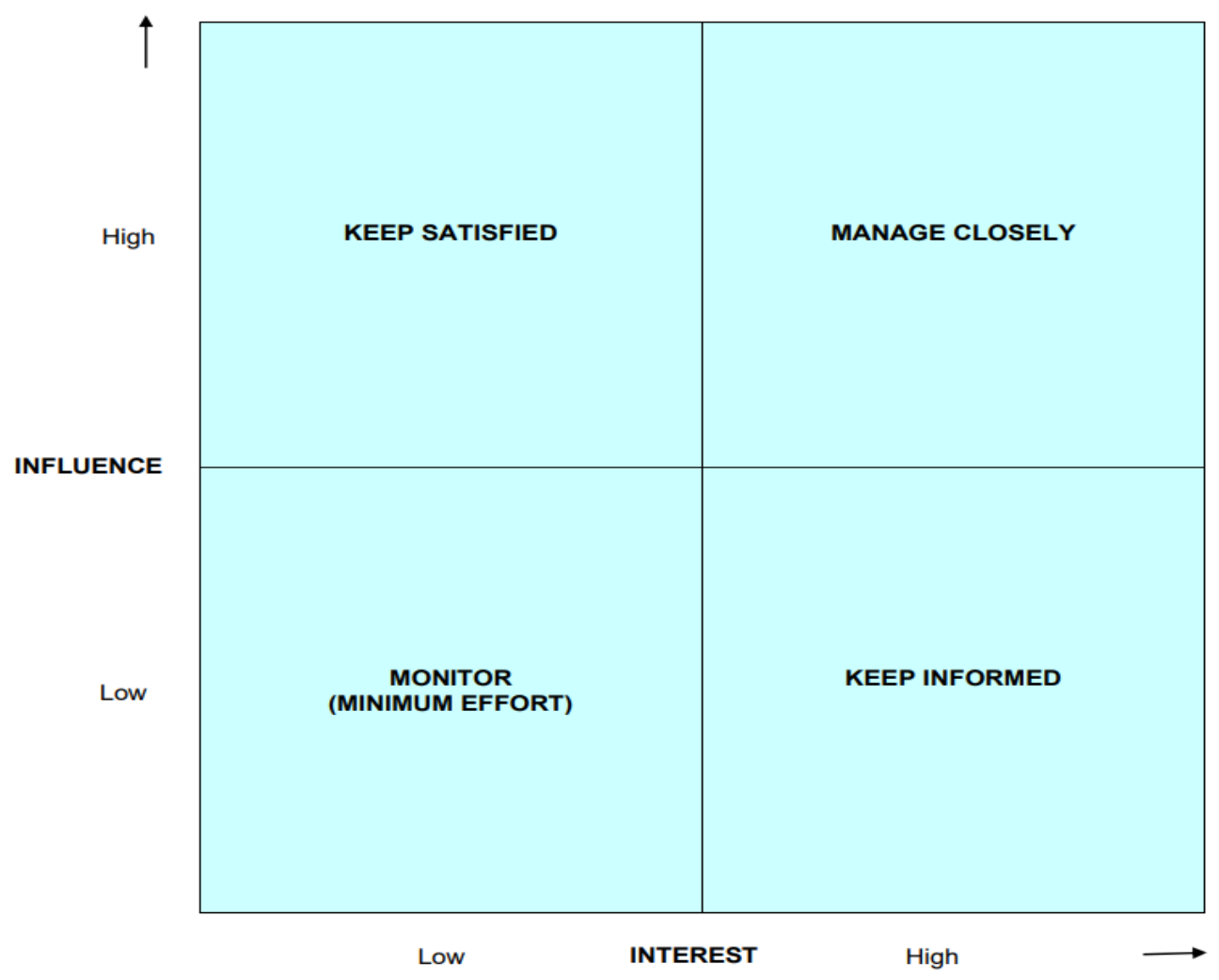

Figure 1: Influence and description of different stakeholders' categories.

\section{RESULT AND DISCUSSION}

\subsection{Overview of stakeholder identification}

The comparison shows that the primary stakeholder groups of campus sustainability are similar in both Sino-foreign universities and Chinese universities (Table 4). Both types of universities own the same structure in the common HEIs, with an extra group "Expert" classified in campus sustainable development. The term Expert in this context refers to those faculty members or researchers whose research area, educational experience, or current 
Table 3: Description of different stakeholders' categories.

\begin{tabular}{|l|l|l|}
\hline & Low interest & High interest \\
\hline $\begin{array}{l}\text { High } \\
\text { influence }\end{array}$ & $\begin{array}{l}\text { High influence, less interested: } \\
\text { Provide sufficient information to } \\
\text { these people to ensure that they are } \\
\text { up to date but not overwhelmed } \\
\text { with data, e.g. the accountable } \\
\text { body (management board or } \\
\text { operations committee) }\end{array}$ & $\begin{array}{l}\text { High influence, interested: } \\
\text { These are the people who must fully } \\
\text { engage and make the most excellent } \\
\text { efforts with, e.g. the head of a } \\
\text { department, who represents the } \\
\text { users/customers }\end{array}$ \\
\hline $\begin{array}{l}\text { Low } \\
\text { influence }\end{array}$ & $\begin{array}{l}\text { Low influence, less interested: } \\
\text { Provide these people with minimal } \\
\text { communication to prevent } \\
\text { boredom, e.g. other departmental } \\
\text { members, teams unaffected by the } \\
\text { change }\end{array}$ & $\begin{array}{l}\text { Low influence, interested: } \\
\text { Keep these people adequately } \\
\text { informed, talk to them to ensure that } \\
\text { no significant issues arise. These } \\
\text { people can help with the detail of the } \\
\text { project, e.g. end users, other project } \\
\text { managers, business community }\end{array}$ \\
\hline
\end{tabular}

teaching module is related to sustainable development in either environment, society, or economy. Thus, the experts are considered different from regular teaching staff in the following analysis.

Table 4: Identified primary stakeholder groups in university campus sustainable development.

\begin{tabular}{|c|c|}
\hline $\begin{array}{l}\text { University of Nottingham Ningbo China } \\
\text { (UNNC) (Sino-foreign university) }\end{array}$ & $\begin{array}{l}\text { Ningbo University (NBU) } \\
\text { (Chinese university) }\end{array}$ \\
\hline University leadership & University leadership \\
\hline \multirow{2}{*}{ 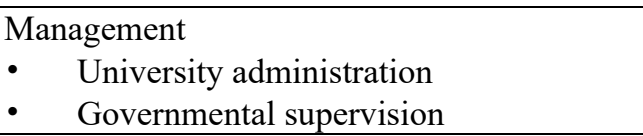 } & University administration \\
\hline & Government \\
\hline Faculty & Faculty \\
\hline Expert (in sustainability) & Expert (in sustainability) \\
\hline Students & Students \\
\hline \begin{tabular}{ll}
\multicolumn{2}{l}{ Society } \\
- & Campus community \\
- & Surrounding residential community \\
- & Surrounding business \\
\end{tabular} & \begin{tabular}{ll}
\multicolumn{2}{l}{ Society } \\
- & Campus community \\
- & Surrounding residential community \\
- & Surrounding business \\
\end{tabular} \\
\hline Company (university as the service provider) & Company (university as the shareholder) \\
\hline
\end{tabular}

Sino-foreign universities have a different leadership framework from that of typical Chinese universities. According to the Higher Education Law of the People's Republic of China, in higher education institutions run by the State, the system shall be applied under which the presidents take overall responsibility under the leadership of the primary committees of the Communist Party of China in higher education institutions. In Chinese 
universities, the positions for the university president and the Party Secretary are assumed by two individuals, with the powerful right held in the Party Secretary; seldom are the two positions filled by a single individual. In contrast, though Sino-foreign university sets the Party Secretary, the secretary's mission is mainly related to government affairs [19]. It is pointed that the governmental supervision is integrated within the university administration in UNNC, while this is set outside of NBU. In China, state-run universities are highly dependent on the local authorities, especially in finance and policy. Thus, the government would play as a more identified stakeholder in NBU than in UNNC. However, it should still be noted that it is unclear the supervision via the party secretary has in decision making and influencing the general sustainability directions at UNNC.

\subsection{The influence and interest spectrum}

By utilizing the influence spectrum, this study provides a better idea of the impact of the stakeholders within both institutions. The results from Table 4 show similarity of local and Sino-foreign university in terms of identified stakeholders. The influence spectrum from both UNNC (Table 5) and NBU (Table 6) categorize those groups identified according to their interest and influence. The results provide insight to the classification that is generally observed in area of planning and decision making within Chinese society, which is the topdown influence. The results also show that from Sino-foreign perspective, top-down influence remains relatively the same i.e., students, faculty and local community have little impact on the key sustainability decisions as compared to university leaders and administration, in spite them being affected the most by these decisions.

Table 5: Stakeholder group categorisation in UNNC.

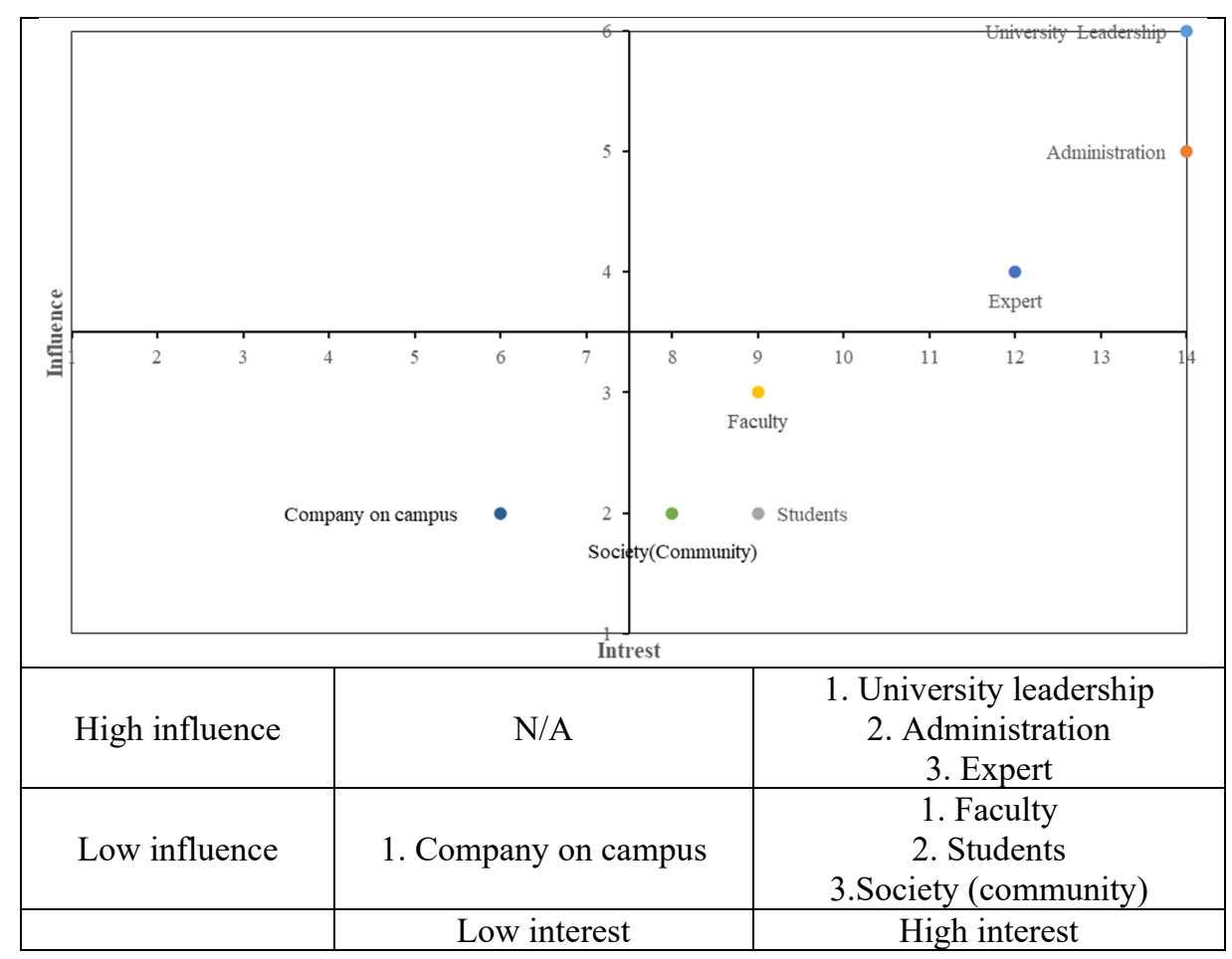


Table 6: Stakeholder group categorisation in Ningbo University.

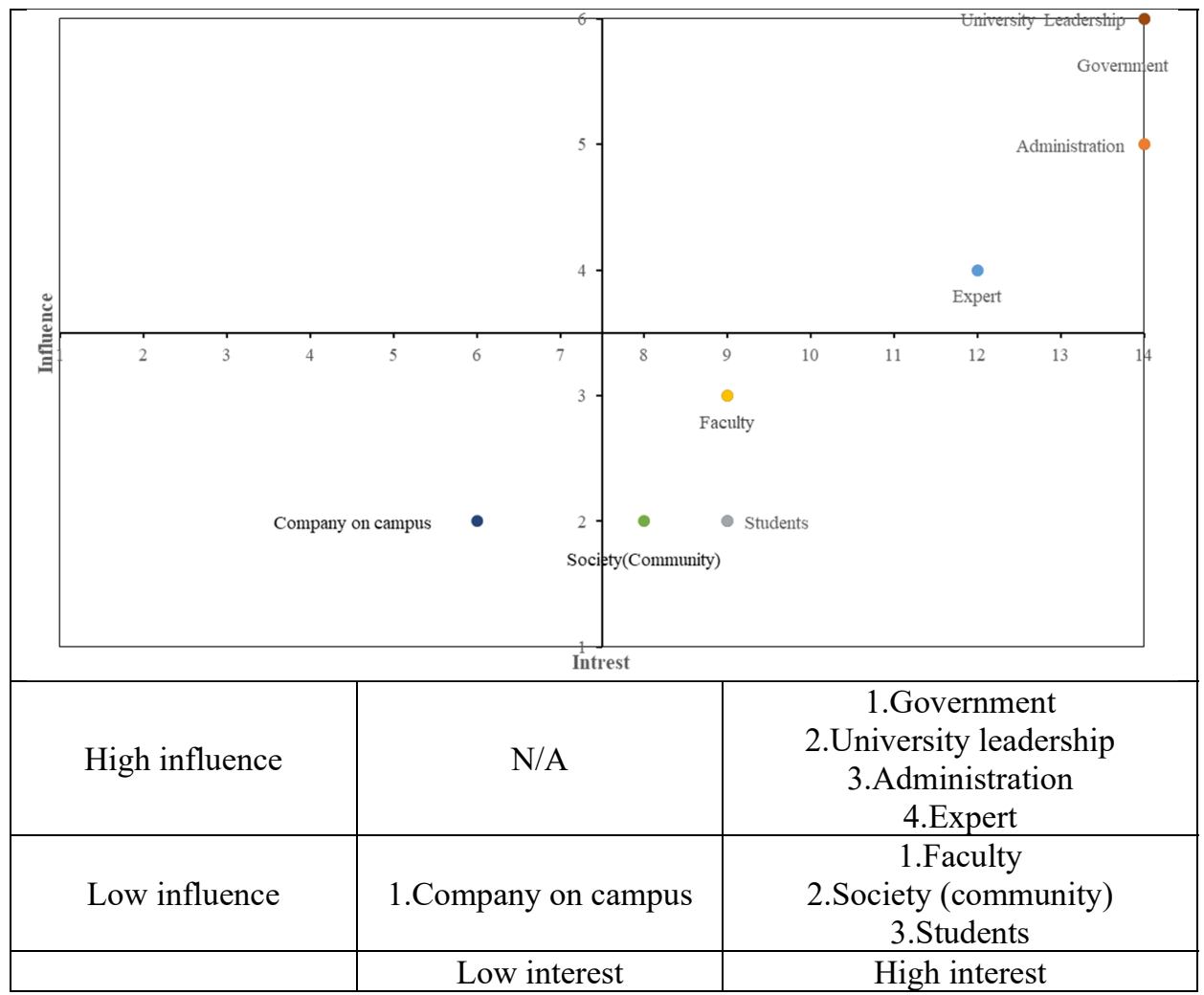

Relating results from Tables $4-6$, the implication would be that the government in both systems have significant influence on the sustainability direction of the institution from topdown vantage points. This is also more impactful due to the current Chinese national plan that is focused on achieving carbon emissions peak by 2030 and carbon neutrality by 2060 thus the current agenda in terms of sustainability is focused on reducing emissions [20]. Within China, this has traditionally been done through the widespread implementation of renewable energy technologies and energy efficacy measures. In fact, reviewing the history of campus sustainability, China began its approach towards sustainability with its ecotechnology demonstration and facility energy management with strong enforcement from the government. A series of regulations and guidelines, such as "The Construction and Management Guidelines of Energy and Resource Conservation Oriented Campus in Colleges and Universities [2008] No.89", "Technical Guidelines of Campus Energy Management System Construction in Colleges and Universities [2009]", etc. was created to provide technical guidance for the construction of an energy and resource conservation-oriented campus [15]. Thus, in both institutions, it is quite likely that their motivation and directions of sustainability will be influenced by the government's sustainability agenda. This could trickle down to the experts that are hired i.e., to say though they have influence in terms of sustainability, this would likely be from research output, consultancy, and advisory perspective. Also, though flexibility may exist in terms of the actual research direction and 
expertise of the institution, this still would still revolve round energy and environmental based activities. The problem with this approach to management is that sustainability, in particular ESD oriented goals needs to consider all dimensions of sustainability i.e., economy, society, environment and institutions, and while it is commendable to address issues of carbon reduction, this does not inherently signify sustainability [21]. Even more so, the very premise of sustainability is based on participatory decision making and inclusivity where the relevant stakeholders are given a meaningful voice. Yet, when UNNC is compared to Ningbo University, only 18 staff are focused on sustainability aspects, with 13 out of those 18 staff focused reducing carbon through energy and pollution-based research. Alternatively, UNNC has 66 staff focused on sustainability-based issues, a stark difference from Ningbo University. This is likely because UNNC is a private Sino-foreign university with larger tuition fees, thus UNNC can afford higher number of staff. A second reason also exists, which is that unlike Ningbo University, whose management is strongly driven by Chinese party objectives. UNNC policies are also driven university mandates and direction which is from the parent campus in the UK. For example, the sustainability strategy is adopted from the UNUK strategy which states that they aim "make an outstanding contribution to supporting the United Nations Sustainable Development Goals (SDGs) through our research and education, our engagement with partners and our behaviour on campus and in our communities. We will place a special emphasis on environmental sustainability, supporting the City of Nottingham's desire to be a net zero carbon city by 2028 and working with partners in China and Malaysia to improve sustainability within their regions" [22]. The key point is that UNUK's management is focused more on sustainable development goals, which is internationally recognised and more balanced in terms of sustainability agenda, while China generally develops a five-year national plan/strategy that is implemented all through the country.

Additionally, it is clearly stated in UNUK sustainability strategy that environmental sustainability would be the primary focus. This is further evident because out of the 66 staff members focused on sustainability at UNNC, 43 of them focus on energy and environmental sustainability research or activities. However, Ningbo University does not have a specific sustainability strategy that exists on universal level, aside the current national mandate of carbon neutrality and carbon peak. This does not infer that other Chinese Universities do not subscribe to international frameworks, as universities such Tongji university in Shanghai is known for the establishment of the UNEP-Tongji Institute of Environment for Sustainable Development (IESD), which was established jointly by the United Nations Environment Programme (UNEP) and Tongji University on May 9, 2002 [5]. Regardless, this does not change the narrative that local mandates and agenda take precedence in China. Coincidently, it so happens that China's carbon neutrality agenda and Nottingham UK zero carbon City agenda align thus allowing for more seamless congruence on goals and less conflicting aims. The question which this paper requires further investigation is, what happens if such interest does not align. Which agenda would supersede the other? Therein lies a world another difference that is beyond the scope of the paper but requires further investigation.

\section{RESULT AND DISCUSSION}

To conclude, the structures of Sino-foreign and Chinese universities are similar in terms of the identification of relevant stakeholders, however, the powers the stakeholder wields varies. Chinese universities have fewer conflicting agenda's but may possess fewer resources than private Sino-foreign universities. Another key point is that within China, the National policy or sustainability agenda largely governs the direction where universities would allocate manpower and financial resources in terms of sustainability, however Sino-foreign 
universities need to contend with national laws or even university policies from the parent university abroad that may create conflict of interest in terms of unified approach to sustainability-based issues on campus. Moreover, through stakeholder analysis, it was made evident that both institutions utilize a top-down approach in terms of ESD and while other less influential stakeholders have high interest, their level is generally limited. A key limitation to this study was that the justification behind the classification of stakeholders and their interest, which was based on online information and data, a follow up study directly interviewing key stakeholders on their influence and interest will be conducted to provide additional context to the stakeholder analysis and offer relevant strategies to optimize inclusivity in ESD within both local and Sino-foreign universities.

\section{ACKNOWLEDGEMENT}

The paper is supported by and part of an ongoing National Natural Science Foundation of China (NSFC) funded project - project code: 72050410358 . We would like to thank and acknowledge our funders for their support.

\section{REFERENCES}

[1] Woo, Y.L., Mokhtar, M., Komoo, I. \& Norzaini, A., Education for sustainable development: A review of characteristics of sustainability curriculum. OIDA International Journal of Sustainable Development, 3(8), pp. 33-44, 2012.

[2] Blasco, N., Brusca, I. \& Labrador, M., Drivers for universities' contribution to the sustainable development goals: An analysis of Spanish public universities. Sustainability, 13(89), 2021. DOI: 10.3390/su13010089.

[3] Mazon, G., Pereira Ribeiro, J.M., de Lima, C.R., Castro, B.C.G. \& Guerra, J.B.S.O.d.A., The promotion of sustainable development in higher education institutions: Top-down bottom-up or neither? International Journal of Sustainability in Higher Education, 21(7), pp. 1429-1450, 2020.

DOI: 10.1108/IJSHE-02-2020-0061.

[4] Du, Y., Arkesteijn, M.H., den Heijer, A.C. \& Song, K., Sustainable assessment tools for higher education institutions: Guidelines for developing a tool for China. Sustainability, 12, 6501, 2020.

[5] Niu, D., Jiang, D. \& Li, F., Higher education for sustainable development in China. International Journal of Sustainability in Higher Education, 11(2), pp. 153-162. DOI: $10.1108 / 14676371011031874$.

[6] Tan, H., Chen, S., Shi, Q. \& Wang, L., Development of green campus in China. Journal of Cleaner Production, 64, pp. 646-653, 2014.

DOI: 10.1016/j.jclepro.2013.10.019.

[7] Wang, J., Yang, M. \& Maresova, P., Sustainable development at higher education in China: A comparative study of students' perception in public and private universities. Sustainability, 12(6), p. 2158, 2020. DOI: 10.3390/su12062158.

[8] Geng, Y. \& Zhao, N., Measurement of sustainable higher education development: Evidence from China. PLoS One, 15(6), e0233747, 2020.

DOI: 10.1371/journal.pone.0233747.

[9] Yuan, X. \& Zuo, J., A critical assessment of the higher education for sustainable development from students' perspectives: A Chinese study. Journal of Cleaner Production, 48, pp. 108-115, 2013. DOI: 10.1016/j.jclepro.2012.10.041.

[10] Tan, H., Chen, S., Shi, Q. \& Wang, L., Development of green campus in China. Journal of Cleaner Production, 64, pp. 646-653, 2014.

DOI: 10.1016/j.jclepro.2013.10.019. 
[11] Li, X., Tan, H. \& Rackes, A., Carbon footprint analysis of student behavior for a sustainable university campus in China. Journal of Cleaner Production, 106, pp. 97108, 2015. DOI: 10.1016/j.jclepro.2014.11.084.

[12] Leal Filho, W. \& Brandli, L., Engaging stakeholders for sustainable development. Engaging Stakeholders in Education for Sustainable Development at University Level, eds. W. Leal Filho \& L. Brandli, Springer: Cham, pp. 335-342, 2016.

DOI: 10.1007/978-3-319-26734-0 21.

[13] Pop, N., Todea, S., Partenie, C. \& Ott, C., Stakeholders' perception regarding sustainable universities. Amfiteatru Economic, 22(54), p. 330, 2020.

DOI: $10.24818 / \mathrm{ea} / 2020 / 54 / 330$.

[14] Koester, R., Eflin, J. \& Vann, J., Greening of the campus: A whole-systems approach. Journal of Cleaner Production, 14(9-11), pp. 769-779, 2006.

DOI: $10.1016 /$ j.jclepro.2005.11.055.

[15] Shuqin, C., Minyan, L., Hongwei, T., Xiaoyu, L. \& Jian, G., Assessing sustainability on Chinese university campuses: Development of a campus sustainability evaluation system and its application with a case study. Journal of Building Engineering, 24, 100747, 2019. DOI: 10.1016/j.jobe.2019.100747.

[16] Alghamdi, N., den Heijer, A. \& de Jonge, H., Assessment tools' indicators for sustainability in universities: An analytical overview. International Journal of Sustainability in Higher Education, 18(1), pp. 84-115, 2017.

DOI: 10.1108/IJSHE-04-2015-0071.

[17] Kioupi, V. \& Voulvoulis, N., Education for sustainable development: A systemic framework for connecting the SDGs to educational outcomes. Sustainability, 11(21), p. 6104, 2019. DOI: 10.3390/su11216104.

[18] Ginige, K., Amaratunga, D. \& Haigh, R., Mapping stakeholders associated with societal challenges: A methodological framework. Procedia Engineering, 212, pp. 1195-1202, 2018. DOI: 10.1016/j.proeng.2018.01.154.

[19] Feng, Y., University of Nottingham Ningbo China and Xi'an Jiaotong-Liverpool University: Globalisation of higher education in China. Higher Education, 65(4), pp. 471-485, 2012. DOI: 10.1007/s10734-012-9558-8.

[20] Chen, X. \& Lin, B., Towards carbon neutrality by implementing carbon emissions trading scheme: Policy evaluation in China. Energy Policy, 157, p. 112510, 2021. DOI: $10.1016 /$ j.enpol.2021.112510.

[21] Dawodu, A., Cheshmehzangi, A. \& Sharifi, A., A multi-dimensional energy-based analysis of neighbourhood sustainability assessment tools: Are institutional indicators really missing? Building Research and Information, 2020.

DOI: $10.1080 / 09613218.2020 .1806701$.

[22] University of Nottingham UK, University of Nottingham Strategy, 2013. https://www.nottingham.ac.uk/strategy/documents/university-strategy.pdf. 